Egyptian

Orthodontic Journal

\title{
EFFECT OF LIP POSITIONS ON FACIAL PROFILE ATTRACTIVENESS IN DIFFERENT ANGLE'S CLASSES OF EGYPTIAN MALES
}

\author{
Mohamed I. Mowafy*
}

ABSTRACT:

Objective: The aim of this study was to evaluate Egyptian male profile attractiveness perception among lay females in different Angle's classifications with different anteroposterior lip positions. Methods: An 18 years old adult Egyptian male whose Lateral Cephalometric readings all were within the first standard deviation of Alexandria analysis was chosen. His lateral profile images were digitally manipulated to produce 27 pictures representing class I, II and III with different anteroposterior lip and nose relations. The images were rated on a 1-27 point score system by 100 females (15-30 years). Comparison among the different classes was done using analysis of variance (ANOV VA) followed by Tukey post hoc test for pair wise comparison. The same tests were used to compare across the different lip/nose positions in each class. The level of significance was set at 5\% for all analyses. Results and conclusions: Class III profile was perceived as the most attractive, while class II was the least with class I in between. Generally a preference towards protrusive profiles over retrusive ones was noted in all classes. In class I the nose position had a more effect on profile attractiveness than lip position. In class II there was more tolerance to nose and lip position. Finally class III showed high sensitivity as regards lip position as any lip retrusion was considered highly unattractive. * Lecturer of orthodontics, Orthodontic department, Faculty of Dentistry, Alexandria
University. 


\section{INTRODUCTION}

Orthodontics is a medical profession with an artistic touch, as patients frequently seek orthodontic treatment not only to adjust their occlusion but mainly to have an attractive smile and appearance. ${ }^{1,2}$

Since beauty is subjective, the orthodontist should not treat his patients according to numbers dictated by various cephalometric readings, or to his own preferences, as self-perception of facial aesthetics does not always correlate with morphometric measurements such as physical characteristics and cephalometric values. ${ }^{3,4}$ Treatment should be based on an understanding of the patient's expectations and delivering the most balanced outcome as regards the patient's will and professional guidelines which the patient might not be aware of. Rivera et $\mathrm{al}^{5}$ reported that the perception of an esthetic profile by patients undergoing orthognathic surgery might not be consistent with those of orthodontists and oral surgeons, and factors as age, gender and ethnicity must be taken into consideration.

It should also be noted that not only is beauty subjective but also changeable and affected by race. For example, at one time, flat retruded lips were considered beautiful while nowadays a lot of females seek lip injections in order to have fuller lips.

An interesting article by Nguyen and Turley in $1998^{6}$ studied the changes in Caucasian male profile in fashion magazines from the 30's till the 90's and found that the ideal male profile had changed towards having more lip protrusion, lip curl and vermilion border display.

The role of ethnicity in esthetic profile perception could be verified by a study by Soh et al $^{7}$ were it was demonstrated that slight lip protrusion was not well accepted in a Chinese community, whereas in another study it was considered attractive in black females. ${ }^{8}$

Ioi et $\mathrm{al}^{9}$ in 2005 studied the effect of anteroposterior lip position with protrusive and retrusive chin positions in Japanese males and females, and showed that as facial convexity decreased more retruded lip 
positions were preferred, for both males and females. Conversely the Japanese orthodontists tended to prefer slightly more protruded lip positions as the facial convexity increased.

Anteroposterior lip positions and their harmony with the chin and nose have great impact on profile attractiveness; therefore this study aims to provide the Egyptian orthodontist with the common Egyptian perception of facial profile beauty in different chin and nose positions. In order to thoroughly understand any differences in the perception of facial attractiveness between clinicians and society, to aid in the further development of patient-centered treatment goals.

\section{MATERIALS AND METHODS}

The subject who participated in this cross sectional analytical study was one male (18 years) patient who was seeking treatment at the Orthodontic department, Faculty of Dentistry, Alexandria University.

He had a pleasing class I profile, a class I malocclusion and his skeletal, dental and soft tissue Lateral Cephalometric analysis readings fell within the $1^{\text {st }}$ standard deviation of the normal Egyptian cephalometric values $^{10}$.

After obtaining a written consent to his approval to participate in this study, his right lateral profile was photographed using a $35-\mathrm{mm}$ SLR $^{*}$ camera (Canon EOS 620) with a $100 \mathrm{~mm}$ focal length lens, from a distance of 10 feet.

The patient was asked to display a relaxed facial expression with the lips closed at rest and the eyes straight ahead with the true horizontal parallel to the floor, and the teeth in maximum intercuspation.

A ruler was held vertically by an assistant at the mid sagital plane in front of the patient, to aid in future metric calibration of the photograph.

\footnotetext{
${ }^{*}$ SLR $=$ Single Lens Reflector
} 
The $10 \times 15-\mathrm{cm}$ color print was then scanned using an HP Scanjet G3110 Photo Scanner ${ }^{\dagger}$, at 300dpi. Adobe Photoshop CS3 ${ }^{\dagger}$ extended version 10.0, was used to convert the color image into a gray scale.

The image was manipulated using Photoshop to create additional 26 new images as follows:

1- Class I group (9 images). The chin was left untouched, the nose and lips were moved $-4 \mathrm{~mm}, 0,+4 \mathrm{~mm}$ in the anteroposterior plane making all possible combinations.

2- Class II group (9 images). The chin was retruded $4 \mathrm{~mm}$, the nose and lips were moved as in group 1.

3- Class III group (9 images). The chin was protruded $4 \mathrm{~mm}$, the nose and lips were moved as in group 1.

The $4 \mathrm{~mm}$ was based on a study by romani et $\mathrm{al}^{11}$ and maple et $\mathrm{al}^{12}$

All vertical relationships were unaltered to evaluate only the anteroposterior aspects of the profile.

The 27 photos of the patient were printed out on glossy paper in a size of $10 \times 15-\mathrm{cm}$ and each photo assigned an alphabetical code according to the changes that had been made to the original photograph. This code key was used after rating the pictures to relate the scores given to a particular picture to its nose and lips modifications.

The profile raters whom participated in this study consisted of 100 laypersons, all of which were females, with an age range of (15-30) years, from the Orthodontic Department Faculty of Dentistry, Alexandria University, and from private orthodontic clinics in Alexandria. Each rater was given the photographs unordered and asked to rank the 27 profiles on a scale of 1 (Least attractive) to 27 (very attractive) without any repeat of rank.

Descriptive statistics were calculated as means and standard deviation for the rating score in different groups and subgroups. Comparison among the different classes was done using analysis of variance (ANOVA) followed by Tukey post hoc test for pair wise comparison.

\footnotetext{
${ }^{\dagger}$ Hewlett Packard Corp, San Diego, Calif.

* Adobe system incorporated, San Jose, Calif.
} 


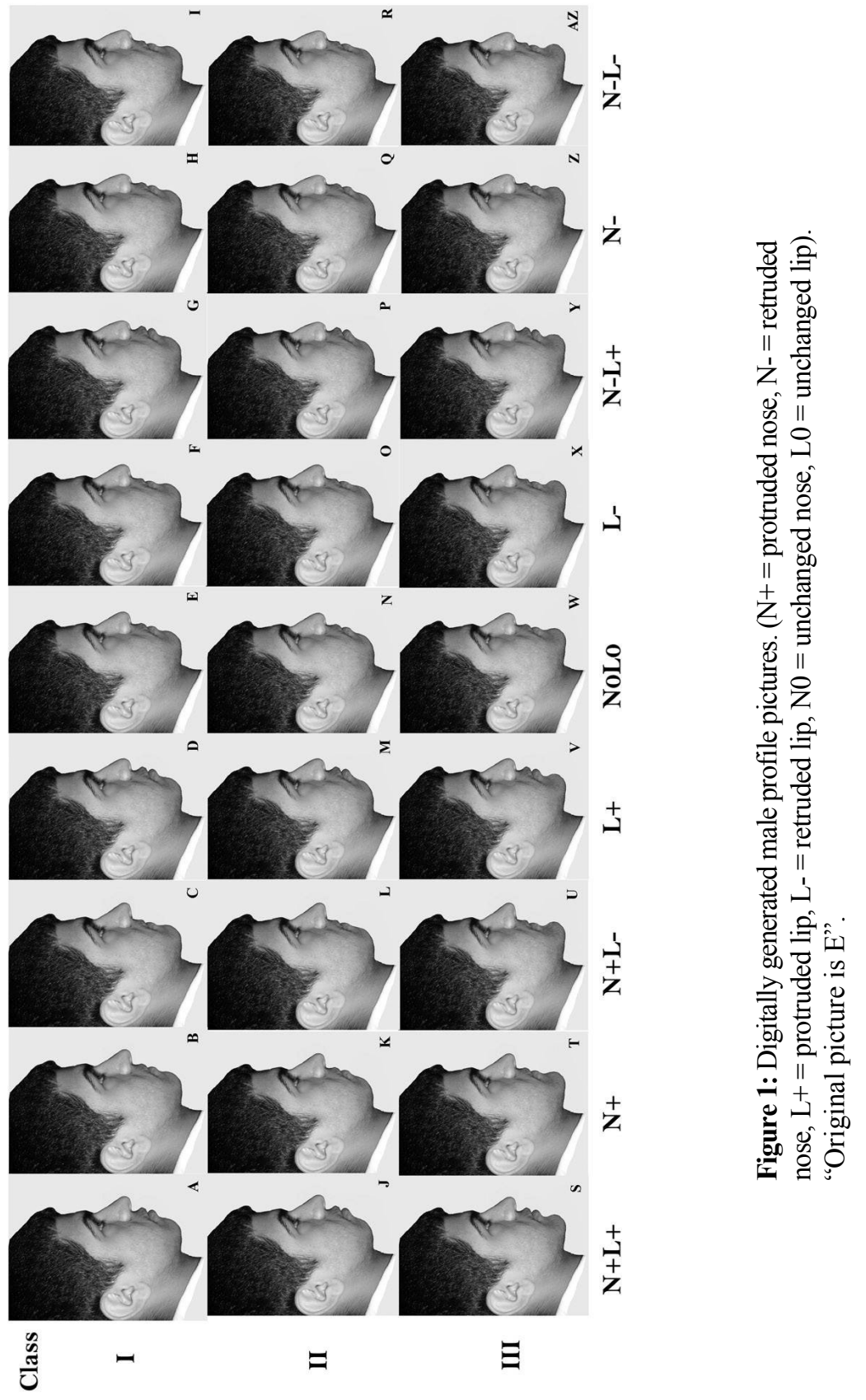


The same test was used to compare across the different lip/nose positions. Regression analysis was used to examine the effect of class and different lip/ nose positions. Significance level was set at 5\%. Bar charts were used for graphical presentation.

\section{RESULTS}

Table 1 and Figure 2 show the mean score and SD of the rating scores in different lip/nose combinations in each of the three classes. It was noted that there was a higher mean score of all class III combinations except when the nose and/ or lips were retruded. It was also noted that class II mean scores were the lowest among the three classes. The different lip/nose combinations led to significant differences in each class in the rating scores, with the highest variation shown by the greatest $F$ value in class III.

Tables 2, 3 and 4 show the pair wise comparison between different nose/lips combinations in class I, II and III respectively. The upper number in each cell represents the mean difference between the pair under comparison, and the lower number represents the significance. Shaded cells show statistically significant differences between pairs.

Table 1: Mean score and standard deviation (SD) of different lip/nose combinations in each of the three classes.

\begin{tabular}{|l|c|c|c|c|c|c|}
\hline \multirow{2}{*}{$\begin{array}{c}\text { Nose lip } \\
\text { combinations }\end{array}$} & \multicolumn{2}{|c|}{ CLASS I } & \multicolumn{2}{c|}{ CLASS II } & \multicolumn{2}{c|}{ CLASS III } \\
\cline { 2 - 7 } & Mean & SD & Mean & SD & Mean & SD \\
\hline N0L0 & 19.33 & 5.60 & 13.98 & 6.69 & 21.50 & 5.54 \\
\hline L- & 17.77 & 5.41 & 11.10 & 6.27 & 11.31 & 7.02 \\
\hline L+ & 18.79 & 5.65 & 13.44 & 7.13 & 23.58 & 4.44 \\
\hline N- & 13.50 & 5.81 & 10.25 & 5.80 & 14.40 & 7.23 \\
\hline N+ & 13.83 & 7.89 & 10.73 & 7.00 & 21.13 & 5.22 \\
\hline N+L+ & 16.29 & 7.68 & 10.15 & 6.84 & 22.65 & 5.52 \\
\hline N-L+ & 12.33 & 6.69 & 7.40 & 5.28 & 17.56 & 6.49 \\
\hline N+L- & 11.79 & 6.40 & 8.44 & 4.77 & 8.56 & 7.02 \\
\hline N-L- & 12.06 & 6.05 & 7.42 & 5.66 & 8.71 & 6.49 \\
\hline $\begin{array}{l}\text { F of ANOVA } \\
\text { P value }\end{array}$ & \multicolumn{2}{|c|}{10.53} & \multicolumn{2}{|c|}{6.92} & \multicolumn{2}{c|}{45.69} \\
\hline
\end{tabular}

$(\mathrm{N}=$ nose, $\mathrm{L}=$ lip, $+=$ protruded, $-=$ retruded, $0=$ unchanged $)$.

*: Statistically significant at $\mathrm{P} \leq 0.05$

Volume 35 - June 2009 


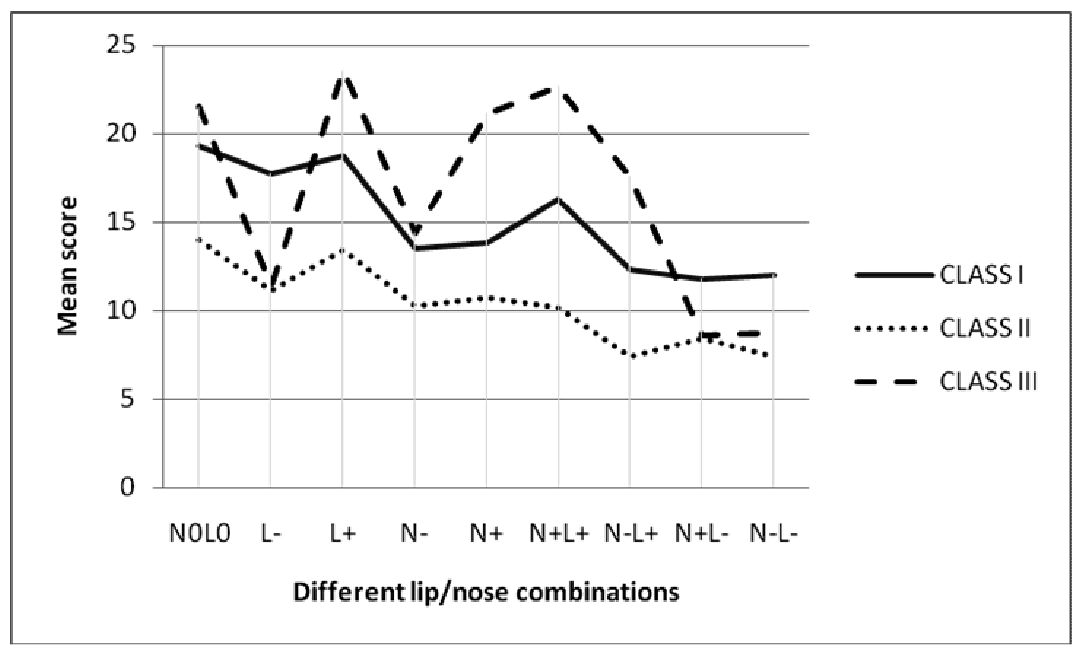

Figure 2: Line graph of mean scores of lip/nose combinations among the 3 classes.

Table 2: Tukey post hoc test for pair wise comparison of different nose/lips combinations in class $I$.

\begin{tabular}{|c|c|c|c|c|c|c|c|c|}
\hline & NOLO & L- & $\mathbf{L}+$ & N- & $\mathbf{N}+$ & $\mathbf{N}+\mathbf{L}+$ & N-L+ & $\mathbf{N}+\mathbf{L}-$ \\
\hline \multicolumn{9}{|l|}{ NOLO } \\
\hline L- & $\begin{array}{c}1.563 \\
.958\end{array}$ & & & & & & & \\
\hline $\mathbf{L}+$ & $\begin{array}{c}.542 \\
1.000\end{array}$ & $\begin{array}{c}-1.021 \\
.997\end{array}$ & & & & & & \\
\hline N- & $\begin{array}{c}5.833(*) \\
.000\end{array}$ & $\begin{array}{c}4.271(*) \\
.032\end{array}$ & $\begin{array}{c}5.292(*) \\
.002\end{array}$ & & & & & \\
\hline $\mathbf{N}+$ & $\begin{array}{c}5.500(*) \\
.001\end{array}$ & $\begin{array}{c}3.938 \\
.068\end{array}$ & $\begin{array}{c}4.958(*) \\
.005\end{array}$ & $\begin{array}{l}-.333 \\
1.000\end{array}$ & & & & \\
\hline $\mathbf{N}+\mathbf{L}+$ & $\begin{array}{c}3.042 \\
.330\end{array}$ & $\begin{array}{c}1.479 \\
.969\end{array}$ & $\begin{array}{c}2.500 \\
.607\end{array}$ & $\begin{array}{c}-2.792 \\
.452\end{array}$ & $\begin{array}{c}-2.458 \\
.629\end{array}$ & & & \\
\hline N-L+ & $\begin{array}{c}7.000(*) \\
.000\end{array}$ & $\begin{array}{c}5.438(*) \\
.001\end{array}$ & $\begin{array}{c}6.458(*) \\
.000\end{array}$ & $\begin{array}{c}1.167 \\
.993\end{array}$ & $\begin{array}{c}1.500 \\
.967\end{array}$ & $\begin{array}{c}3.958 \\
.065\end{array}$ & & \\
\hline $\mathbf{N}+\mathbf{L}-$ & $\begin{array}{c}7.542(*) \\
.000\end{array}$ & $\begin{array}{c}5.979(*) \\
.000\end{array}$ & $\begin{array}{c}7.000(*) \\
.000\end{array}$ & $\begin{array}{c}1.708 \\
.929\end{array}$ & $\begin{array}{c}2.042 \\
.826\end{array}$ & $\begin{array}{c}4.500(*) \\
.018\end{array}$ & $\begin{array}{c}.542 \\
1.000\end{array}$ & \\
\hline N-L- & $\begin{array}{c}7.271(*) \\
.000\end{array}$ & $\begin{array}{c}5.708\left(^{*}\right) \\
.001\end{array}$ & $\begin{array}{c}6.729(*) \\
.000\end{array}$ & $\begin{array}{c}1.438 \\
.974\end{array}$ & $\begin{array}{c}1.771 \\
.914\end{array}$ & $\begin{array}{c}4.229(*) \\
.036\end{array}$ & $\begin{array}{c}.271 \\
1.000\end{array}$ & $\begin{array}{l}-.271 \\
1.000\end{array}$ \\
\hline
\end{tabular}

*: Statistically significant at $\mathrm{P} \leq 0.05$ 


\section{Egyptian}

Orthodontic Journal

Table 3: Tukey post hoc test for pair wise comparison of different nose/lips combinations in class II.

\begin{tabular}{|c|c|c|c|c|c|c|c|c|}
\hline & NOLO & L- & $\mathbf{L}+$ & N- & $\mathbf{N}+$ & $\mathbf{N}+\mathbf{L}+$ & N-L+ & $\mathbf{N}+\mathbf{L}-$ \\
\hline NOL0 & & & & & & & & \\
\hline L- & $\begin{array}{c}2.875 \\
.364\end{array}$ & & & & & & & \\
\hline $\mathbf{L}+$ & $\begin{array}{c}.542 \\
1.000\end{array}$ & $\begin{array}{c}-2.333 \\
.655\end{array}$ & & & & & & \\
\hline N- & $\begin{array}{l}3.729 \\
.082\end{array}$ & $\begin{array}{l}.854 \\
.999\end{array}$ & $\begin{array}{l}3.188 \\
.228\end{array}$ & & & & & \\
\hline $\mathbf{N}+$ & $\begin{array}{l}3.250 \\
.205\end{array}$ & $\begin{array}{l}.375 \\
1.000\end{array}$ & $\begin{array}{c}2.708 \\
.450\end{array}$ & $\begin{array}{l}-.479 \\
1.000\end{array}$ & & & & \\
\hline $\mathbf{N}+\mathbf{L}+$ & $\begin{array}{c}3.833 \\
.065\end{array}$ & $\begin{array}{l}.958 \\
.998\end{array}$ & $\begin{array}{c}3.292 \\
.191\end{array}$ & $\begin{array}{l}.104 \\
1.000\end{array}$ & $\begin{array}{l}.583 \\
1.000\end{array}$ & & & \\
\hline N-L+ & $\begin{array}{c}6.583(*) \\
.000 \\
\end{array}$ & $\begin{array}{c}3.708 \\
.086 \\
\end{array}$ & $\begin{array}{c}6.042(*) \\
.000\end{array}$ & $\begin{array}{c}2.854 \\
.374 \\
\end{array}$ & $\begin{array}{c}3.333 \\
.177\end{array}$ & $\begin{array}{c}2.750 \\
.428\end{array}$ & & \\
\hline $\mathbf{N}+\mathbf{L}-$ & $\begin{array}{c}5.542(*) \\
.001\end{array}$ & $\begin{array}{c}2.667 \\
.472\end{array}$ & $\begin{array}{c}5.000(*) \\
.003\end{array}$ & $\begin{array}{l}1.813 \\
.886 \\
\end{array}$ & $\begin{array}{c}2.292 \\
.677 \\
\end{array}$ & $\begin{array}{c}1.708 \\
.916\end{array}$ & $\begin{array}{c}-1.042 \\
.996 \\
\end{array}$ & \\
\hline N-L- & $\begin{array}{c}6.563(*) \\
.000\end{array}$ & $\begin{array}{l}3.688 \\
.089\end{array}$ & $\begin{array}{c}6.021(*) \\
.000\end{array}$ & $\begin{array}{c}2.833 \\
.385\end{array}$ & $\begin{array}{l}3.313 \\
.184\end{array}$ & $\begin{array}{c}2.729 \\
.439\end{array}$ & $\begin{array}{l}-.021 \\
1.000\end{array}$ & $\begin{array}{c}1.021 \\
.997\end{array}$ \\
\hline
\end{tabular}

*: Statistically significant at $\mathrm{P} \leq 0.05$

Table 4: Tukey post hoc test for pair wise comparison of different nose/lips combinations in class III.

\begin{tabular}{|c|c|c|c|c|c|c|c|c|}
\hline & NOLO & L- & $\mathbf{L}+$ & N- & $\mathbf{N}+$ & $\mathbf{N}+\mathbf{L}+$ & N-L+ & $\mathbf{N}+\mathbf{L}-$ \\
\hline \multicolumn{9}{|l|}{ NOLO } \\
\hline L- & $\begin{array}{c}10.188(*) \\
.000\end{array}$ & & & & & & & \\
\hline $\mathbf{L}+$ & $\begin{array}{c}-2.083 \\
.775 \\
\end{array}$ & $\begin{array}{c}-12.271(*) \\
.000\end{array}$ & & & & & & \\
\hline N- & $\begin{array}{c}7.104(*) \\
.000\end{array}$ & $\begin{array}{c}-3.083 \\
.262\end{array}$ & $\begin{array}{c}9.188(*) \\
.000\end{array}$ & & & & & \\
\hline $\mathbf{N}+$ & $\begin{array}{c}.375 \\
1.000\end{array}$ & $\begin{array}{c}-9.813(*) \\
.000\end{array}$ & $\begin{array}{c}2.458 \\
.579\end{array}$ & $\begin{array}{c}-6.729(*) \\
.000\end{array}$ & & & & \\
\hline $\mathbf{N}+\mathbf{L}+$ & $\begin{array}{c}-1.146 \\
.992\end{array}$ & $\begin{array}{c}-11.333(*) \\
.000\end{array}$ & $\begin{array}{l}.938 \\
.998\end{array}$ & $\begin{array}{c}-8.250\left(^{*}\right) \\
.000\end{array}$ & $\begin{array}{c}-1.521 \\
.955\end{array}$ & & & \\
\hline N-L+ & $\begin{array}{c}3.938(*) \\
.049\end{array}$ & $\begin{array}{c}-6.250(*) \\
.000\end{array}$ & $\begin{array}{c}6.021(*) \\
.000\end{array}$ & $\begin{array}{c}-3.167 \\
.229\end{array}$ & $\begin{array}{c}3.563 \\
.111\end{array}$ & $\begin{array}{c}5.083(*) \\
.002\end{array}$ & & \\
\hline $\mathbf{N}+\mathbf{L}-$ & $\begin{array}{c}12.938(*) \\
.000\end{array}$ & $\begin{array}{c}2.750 \\
.420\end{array}$ & $\begin{array}{c}15.021(*) \\
.000\end{array}$ & $\begin{array}{c}5.833(*) \\
.000\end{array}$ & $\begin{array}{c}12.563(*) \\
.000\end{array}$ & $\begin{array}{c}14.083(*) \\
.000\end{array}$ & $\begin{array}{c}9.000(*) \\
.000\end{array}$ & \\
\hline N-L- & $\begin{array}{c}12.792(*) \\
.000\end{array}$ & $\begin{array}{c}2.604 \\
.498\end{array}$ & $\begin{array}{c}14.875(*) \\
.000\end{array}$ & $\begin{array}{c}5.688(*) \\
.000\end{array}$ & $\begin{array}{c}12.417(*) \\
.000\end{array}$ & $\begin{array}{c}13.938(*) \\
.000\end{array}$ & $\begin{array}{c}8.854(*) \\
.000\end{array}$ & $\begin{array}{l}-.146 \\
1.000\end{array}$ \\
\hline
\end{tabular}

*: Statistically significant at $\mathrm{P} \leq 0.05$ 
Table 5 Shows the comparison among the three classes as regards the mean rating score. The difference among these classes was statistically significant ( $\mathrm{F}=86.38, \mathrm{P}<0.0001)$. Post hoc comparison shows that significant differences also exist between the mean rating score of Class I and II, I and III as well as II and III, with class III having the highest score followed by class I and then class II.

Table 5: ANOVA for mean scores among different classes.

\begin{tabular}{|l|c|c|c|}
\hline & Class I & Class II & Class III \\
\hline Mean \pm SD & $15.08 \pm 6.95^{\mathrm{a}}$ & $10.32 \pm 6.54^{\mathrm{b}}$ & $16.60 \pm 8.35^{\mathrm{c}}$ \\
\hline F of ANOVA & \multicolumn{3}{|c|}{86.38} \\
P value & $<0.0001^{*}$ \\
\hline
\end{tabular}

*: Statistically significant at $\mathrm{P} \leq 0.05$.

a, b, c: different letters denoting statistically significant differences

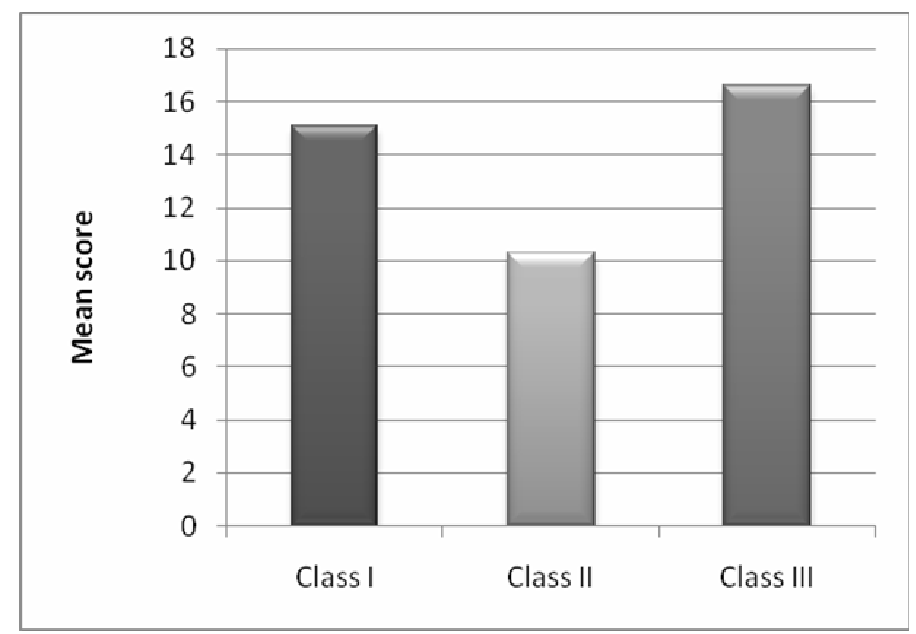

Figure 3: Bar graph of mean scores among different classes.

Table 2 shows the regression model for factors affecting the rating scores. Class, position of lip and nose as well as different combinations of lip and nose positions in different classes significantly affected the rating score $(\mathrm{P}<0.0001$ for all). 
Egyptian

Orthodontic Journal

Table 2: Regression model for factors affecting rating score

\begin{tabular}{|l|c|c|}
\hline \multicolumn{1}{|c|}{ Factors } & F & P value \\
\hline Class & 118.01 & $<0.0001^{*}$ \\
\hline Position of lip and nose & 41.99 & $<0.0001^{*}$ \\
\hline Class * position of lip and nose & 10.10 & $<0.0001^{*}$ \\
\hline
\end{tabular}

\section{DISCUSSION}

In this study the raters were chosen to be females because a person is more interested to be found attractive by the opposite sex, rather than peers. The age range was chosen to be (15-30) to coincide with the most fertile period of a female, when judging the possible mate attractiveness is at its peak ${ }^{13}$.

The patient was photographed using a $100 \mathrm{~mm}$ focal length lens, from a distance of 10 feet, and then the images printed and scanned to keep barrel distortion to a minimum, i.e. to avoid foreshortening ${ }^{*}$ commonly seen when using digital cameras for portrait shots.

Black and-white digital images were used to eliminate any possible influence of skin and hair color.

Although the visual analogue scale VAS is a simple and rapid method for giving scores, it was not used in this study because there remain many concerns when using this instrument to measure a subjective phenomenon such as facial attractiveness. For example, it is difficult to ensure that all raters interpret the anchor points of "Least attractive" and "very attractive" in exactly the same way or that comparable positioning of the marks on the scale implies the same feeling or intensity of feeling by the same or different raters. ${ }^{14}$ Furthermore, it should not be assumed that the same score by different raters implies the same assessment of a particular profile.

\footnotetext{
* Making facial parts closer to the lens (as the nose or chin) appear relatively larger than the rest of the face.
} 
The regression model shown in table 7 indicates that factors as class, lip/nose position and interaction between the class and lip/nose position significantly affect the perception of facial profile attractiveness.

Class III was considered by the layout females more attractive than class I, this matches the conclusions of psycho sociologists that a welldeveloped mandible with a strong chin in men is a desirable secondary sexual characteristic associated with good facial attractiveness and preferred mate selection by women. ${ }^{15,16}$

Class II had the lowest scores indicating it being the least preferred, this goes along with the findings of a study by Cochrane et $\mathrm{al}^{17}$ who found that Class II profile was generally perceived to be the least attractive by the public in a white population. Our findings contradict the findings of Soh et $\mathrm{al}^{7}$ that Chinese males with retrusive mandibles were attractive, and the findings of Ioi et al ${ }^{9}$ that Japanese also liked retrusive profiles. Kurado et $\mathrm{al}^{18}$ reported that Japanese liked retrusive mandibles. Such a contrasting result could be due to cultural and ethnic factors that had influenced the perception, with whites and African having closer beauty standards than Chinese.

In Class I, changes in the nose position had a more profound effect on the profile attractiveness than lip positions as evident by table 2 where NOL0 was significantly higher than $\mathrm{N}+$ and $\mathrm{N}$ - but not significantly different than L+ and L-.

When comparing the nose lips combination together it could be seen that when ever an element of retrusion was applied either to the nose or the lip the NOL0 was significantly better, whereas when both lips and nose were protruded it wasn't significantly different, indicating a public acceptance of protrusion in males, matching the findings of Nguyen and Turley ${ }^{6}$, and Hier et $\mathrm{al}^{19}$

In Class I with a big nose it is more accepted to leave the lips with some degree of protrusion, than to be retruded, as indicated by $\mathrm{N}+\mathrm{L}+$ being not significantly different than the normal profile NOL0 nor than the profile with only a retruded lip, but was significantly better than $\mathrm{N}+\mathrm{L}-$, and was also significantly better than N-L- indicating again the preference of protrusive profile than retrusive one in males. In case of a small nose lip positions didn't make any significant difference. 
In class II there was generally more tolerance to changes in lips and nose position than in class I, as indicated in table 3 by the fewer number of pair comparison showing significant differences. However a normally positioned nose and lip or protruded lips with a normal nose were better accepted than retruded lips with a large nose, protruded lips with a small nose, and both retrusive lips and nose, indicating a general preference of a protrusive profile than a retrusive one.

In class III any sort of retrusion to the lips or nose was considered unattractive, because the protrusion of the lips and/or nose makes the protruded chin appear less prominent. A retruded lip was significantly less attractive than a protruded lip, big nose, both a protruded lip and a big nose and even a small nose with protruded lips. Indicating that the lip chin relation influences the public perception of attractiveness more the lip nose relation in class III. A close look at table 4 shows that any combination with lips retrusion was considered unattractive, indicating the extreme caution one should exercise in class III cases requiring extraction not to over retract the anterior teeth so not to cause lip retrusion.

\section{CONCLUSIONS}

1- Class III is more favored in males while class II is the least attractive.

2- There is better acceptance of male protrusive profile by Egyptian females than a retrusive one in all classes.

3- In class I the nose prominence has more effect on profile beauty than lips position.

4- In class II there is more tolerance to changes in lips and nose positions.

5- Any lip retrusion in class III is deemed highly unattractive, regardless of the nose position. Therefore one must be cautious when planning class III treatment as regard lip position, as the lip chin relation has a more effect on profile attractiveness than the nose lip relation.

\section{Recommendation:}

1- A similar study should be made among Egyptian females, with the raters being males.

2- Updated Egyptian cephalometric analysis normal values should be made, one for each sex. As the perception of beauty changes over time. 


\section{REFERENCES}

1- Romani KL, Agahi F, Nanda R, Zernik JH. Evaluation of horizontal and vertical differences in facial profiles by orthodontists and lay people. Angle Orthod 1993;63:175-82.

2- Kilpelanien P, Phillips C, Tulloch JFC. Anterior tooth position and motivation for early treatment. Angle Orthod 1993;63:171-4.

3- Bell R, Kiyak HA, Joondeph DR, McNeill RW, Wallen TR. Perceptions of facial profile and their influence on the decision to undergo orthognathic surgery. Am J Orthod 1985;88:323-32.

4- Wilmot JJ, Barber HD, Chou DG, Vig KWL. Associations between severity of dentofacial deformity and motivation for orthodontic-orthognathic surgery treatment. Angle Orthod 1993; 63:283-8.

5- Rivera SM, Hatch JP, Dolce C, Bays RA, Van Sickels JE, Rugh JD. Patients' own reasons and patient-perceived recommendations for orthognathic surgery. Am J Orthod Dentofacial Orthop 2000;118:134-40.

6- Nguyen DD, Turley P. Changes in the Caucasian male facial profile as depicted in fashion magazines during the twentieth century. Am J Orthod Dentofacial Orthop 1998;114:208-17.

7- Soh J, Chew MT, Wong HB. A comparative assessment of the perception of Chinese facial profile esthetics Am J Orthod Dentofacial Orthop 2005;127:692-9.

8- Yehezkel S, Turley PK. Changes in the African American female profile as depicted in fashion magazines during the 20th century. Am J Orthod Dentofacial Orthop 2004;125:407-17.

9- Ioi H, Nakata S, Nakasima A, Counts A. Effect of facial convexity on antero-posterior lip positions of the most favored Japanese facial profiles. Angle Orthod 2005;75:326-32.

10- Aboul-Azm SF, Enany NM, Fahmy MA, Tamish NO, Abdalah HE. The Alexandria Analysis: Radiographic Cephalometric Standards for Egyptian adults. Alexandria Dental Journal 1984; vol 9, no.1. 
11- Romani KL, Agahi F, Nanda R, Zernik JH. Evaluation of horizontal and vertical differences in facial profiles by orthodontists and lay people. Angle Orthod 1993;63:175-82.

12- Maple JR, Vig KWL, Beck FM, Larsen PE, Shanker S. A comparison of providers' and consumers' perceptions of facial-profile attractiveness. Am J Orthod Dentofacial Orthop 2005;128:690-6.

13- Cohen M, Sauer M. Fertility in perimenopausal women. Clin Obstet Gynecol 1998;41(4):958-65.

14- Aitken RCB. Measurement of feelings using visual analogue scales. Proc R Soc Med 1969;62:17-21. Quoted in Maple JR, Vig KWL, Beck FM, Larsen PE, Shanker S. A comparison of providers' and consumers' perceptions of facial-profile attractiveness. Am J Orthod Dentofacial Orthop 2005;128:690-6.

15- Grammer K, Thornhill R. Human (Homo sapiens) facial attractiveness and sexual selection: the role of symmetry and averageness. J Comp Psychol 1994;108;233-42. Quoted in Soh J, Chew MT, Wong HB. A comparative assessment of the perception of Chinese facial profile esthetics Am J Orthod Dentofacial Orthop 2005;127:692-9.

16- Thornhill R, Gangestad, SW. Facial attractiveness. Trends in Cognitive Sciences 1999;3:452-9. Quoted in Soh J, Chew MT, Wong HB. A comparative assessment of the perception of Chinese facial profile esthetics Am J Orthod Dentofacial Orthop 2005;127:692-9.

17- Cochrane SM, Cunningham SM, Hunt SP. A comparison of the perception of facial profile by the general public and 3 groups of clinicians. Int $\mathbf{J}$ Adult Orthod Orthognath Surg 1999; 14:291-5.

18- Kuroda S, Sugahara T, Takabatake S, Taketa H, Ando R, TakanoYamamoto T. Influence of anteroposterior mandibular positions on facial attractiveness in Japanese adults Am J Orthod Dentofacial Orthop. 2009 Jan;135(1):73-8.

19- Hier LA, Evans CA, BeGole EA, Giddon DB. Comparison of preferences in lip position using computer animated imaging. Angle Orthod 1999; 69:231-8. 